\title{
Bromodomain-Containing Protein 7
}

National Cancer Institute

\section{Source}

National Cancer Institute. Bromodomain-Containing Protein 7. NCI Thesaurus. Code C157265.

Bromodomain-containing protein $7(651 \mathrm{aa}, \sim 74 \mathrm{kDa})$ is encoded by the human BRD7 gene. This protein plays a role in p53-dependent G1/S phase arrest, SWI/SNF-mediated chromatin remodeling and Wnt signaling. 